\title{
ROBOT LENGAN PEMINDAH BARANG OTOMATIS BERBASIS ARDUINO MENGGUNAKAN SENSOR WARNA
}

\author{
Sumardi \\ e-mail : sumardi@stmikbpn.ac.id
}

\begin{abstract}
ABSTRAK
Robot lengan pemindah barang otomatis berbasis arduino menggunakan sensor warna, Alat yang dirancang ini bertujuan untuk mengurangi peran manusia dalam pengelompokan atau sortir barang dengan alat sortir sehingga dapat meminimalisir pengaruh inkonsistensi manusia dalam aktivitas tersebut. Alat ini juga sebagai simulasi serta media pembelajaran. Metode analisis data yang digunakan yaitu analisis kebutuhan yang mencakup perangkat lunak yaitu OS, dan Software Arduino, serta perangkat keras berupa Laptop, Arduino, Sensor RGB, dan Motor Servo.

Dari hasil pengujian yang telah dilakukan dapat disimpulkan bahwa Robot ini dapat berjalan dengan baik pada saat membaca warna box dan menempatkan box tersebut sesuai dengan tempat wadahnya. Kesimpulan dari alat yang dirancang sebagai media angkut barang, lengan robot dapat diaplikasikan menggunakan beberapa servo dalam jumlah dof tertentu.
\end{abstract}

Kata Kunci: Arduino Uno, Sensor RGB, Motor Servo, Robot Lengan.

\section{ABSTRACT}

Robot arm transporter using arduino-based sensor auto color, a tool designed to this aim to reduce human role in grouping or sorting goods with the sort tool so that it can minimize the influence of inconsistencies humans in the event. This tool as well as a simulation as well as the media of instruction. Methods of data analysis used IE needs analysis that includes software that is the OS, and the Arduino Software, and hardware in the form of a Laptop, Arduino, Sensor, RGB and Servo Motor.

From the results of testing that has been done can be inferred that this Robot can run well at a time when reading the color box and put the box in accordance with the location of their vessels. Conclusion of the tool is designed as a medium transport goods, robotic arm can be applied using several servo in the number of dof.

Keywords: Arduino Uno, RGB Sensor, Servo Motor, The Robot Arm.

\section{PENDAHULUAN}

Perkembangan teknologi mengalami banyak evolusi salah satunya yaitu teknologi robotika. Hal ini terlihat dari perkembangan pemindahan barang terkena dampaknya. Yang dihasilkan dan terjadinya interaksi sosial antara teknologi terhadap pengguna. Perkembangan ini sudah banyak memberikan kemudahan dan keuntungan tersendiri kepada penggunan. Munculnya teknologi merupakan salah satu tuntutan dan kebutuhan dari manusia yang menginginkan kemudahan dalam kehidupannya.

Pada dasarnya, Robot merupakan piranti mekanik elektrik atau elektronika yang bekerja secara otomatis yang dapat bekerja sendiri tanpa pengendalian dari luar. Sementara itu dalam arti luas robot berarti suatu sistem yang terdiri dari mekanisme mekanik yang memiliki suatu kontrol elektris untuk melaksanakan tugas tertentu. Dalam perkembangannya, robot mulai digunakan dalam segala bidang tak terkecuali pada industri dalam pelaksanaan produksinya. Dengan menggunakan robot dalam kegiatan produksi, proses produksi akan lebih efisien dan efektif. Robot juga memiliki tingkat ketelitian yang tinggi jika dibandingkan dengan tenaga manusia.

Dalam penelitian ini peneliti membuat sebuah prototipe robot yang dapat mengenali benda berdasarkan warna dengan menggunakan mikrokontroler berbasis arduino uno. Robot ini dirancang untuk mempermudah kerja manusia dalam melakukan tugasnya dalam menyortir barang.

\section{LANDASAN TEORI}

Fina Supegina dan Dede Sukindar (2014), Pada rancangan penelitian ini dibuat sebuah robot yang 
dapat mengenali benda berdasarkan warna dan ditampilkan pada LCD dengan menggunakan mikrokontroler berbasis arduino uno. Robot akan mengelompokkan barang (box) yang sejenis secara otomatis. Robot ini mendekteksi 6 macam warna yaitu merah muda, hijau, biru, orange, hitam dan putih. Warna-warna tersebut dideteksi dengan menggunakan sensor warna yang memiliki output frekuensi, besar frekuensi yang dihasilkan tergantung dari panjang gelombang warna objek dan Intensitas cahayanya. Sedangkan sebagai pusat kendalinya menggunakan mikrokontroler berbasis arduino uno yang deprogram menggunakan bahasa C. Dari hasil pengujian yang telah dilakukan dapat disimpulkan bahwa Robot ini dapat berjalan dengan baik pada saat membaca warna box dan menempatkan box tersebut sesuai dengan tempatnya serta warna tersebut ditampilkan pada LCD dan manfaat penggunaan robot dalam penyortiran akan lebih efisien dan efektif. Rangkaian ultrasonik, dan rangkaian sensor warna yang merupakan rangkaian sensor sebagai input untuk mikrokontroler AT89S52. Rangkaian ultrasonik akan menghasilkan sinyal yang akan diolah oleh rangkaian penerima ultrasonik sehingga menghasilkan sebuah data dengan logika 0 kepada port 3 sebagai input yang nantinya data akan diproses sebagai acuan untuk menentukan output di port 0. Sensor warna juga akan menghasilkan sinyal yang nantinya akan masuk mikrokontroler. Output mikrokontroler akan menghasilkan logika 1 untuk mengaktifkan driver motor pada pin IC L 293D untuk mengaktifkan motor kaki kanan, kaki kiri, dan tangan robot. Motor DC digunakan sebagai penggerak robot sehinggarobot dapat bergerak mobile yaitu dapat bergerak maju, mundur, belok kiri, dan belok kanan, Penggunaan 3 sensor pada Robot yaitu sensor ultrasonik kanan, kiri, depan sebagai pengindra robot mempermudah sistim kerja robot sesuai dengan rancangan.

\section{Mikrokontroler}

\section{Teori-Teori yang Digunakan}

Mikrokontroler adalah suatu chip atau IC (Integrated Circuit) yang bisa di program menggunakan komputer. Program yang direkam bertujuan agar rangkaian elektronik dapat membaca input, memproses, dan kemudian mengasilkan output sesuai yang diinginkan. Outputnya itu bisa berupa sinyal, besaran tegangan, lampu, suara, getaran, gerakan, dan sebagainya (2015:1).

Mikrokontroler merupakan teknologi semikonduktor yang terdiri dari rangkaian transistor dengan ukuran yang kecil. Mikrokontroler dapat digunakan secara fleksibel dan efektif dalam mengontrol berbagai peralatan elektronik (2017:84).

Dengan pengertian diatas dapat ditarik kesimpulan bahwa mikrokontroler merupakan suatu rangkaian atau sirkuit yang dapat di program menggunakan komputer secara fleksibel dan efektif dalam mengontrol berbagai peralatan elektronik bahkan menghasilkan output sesuai yang diinginkan.

\section{Arduino}

Menurut Abdul Kadir (2016:2), Arduino merupakan perangkat keras sekaligus perangkat lunak yang memungkinkan siapa saja melakukan pembuatan prototipe suatu rangkaian elektronika yang berbasis mikrokontroler dengan mudah dan cepat. Sejak awal peluncuran hingga sekarang, Uno telah berkembang menjadi versi Revisi 3 atau biasa ditulis REV 3 atau R3. Software Arduino IDE, yang bisa diinstall di Windows maupun Mac dan Linux, berfungsi sebagai software yang membantu anda memasukkan (upload) program

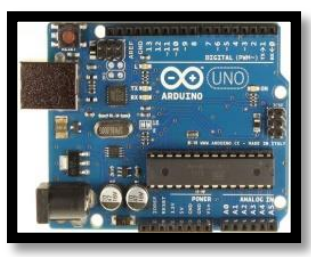

ke chip ATMega328 dengan mudah.

\section{METODOLOGI PENELITIAN}

\section{Metode Pengumpulan Data}

Metode pengumpulan data merupakan teknik atau cara yang dilakukan untuk mengumpulkan data. Pada penelitian ini penulis menggunakan metode pengumpulan data dengan cara:

- Observasi dan Pengamatan

Teknik pengumpulan data dengan langsung terjun ke lapangan untuk mengamati permasalahan yang terjadi secara langsung, yang tak menentu di tempat kejadian secara sistematik kejadiankejadian, perilaku, objek-objek yang dilihat dan hal-hal lain yang diperlukan dalam mendukung penelitian yang sedang berlangsung.

- Studi Literatur

Studi Literatur adalah salah satu metode pengumpulan data dengan cara membaca bukubuku dan jurnal sesuai dengan data

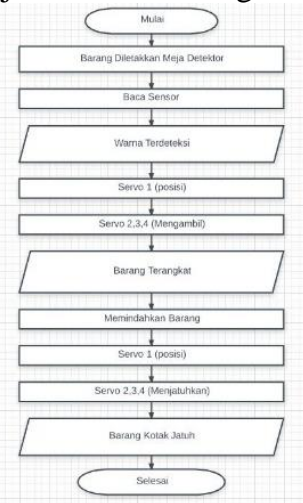


yang dibutuhkan. Pada penelitian ini penulis memilih studi literatur untuk mengumpulkan referensi dari buku-buku mengenai mikrokontroler serta jurnal yang membahas tentang mikrokontroler arduino.

dijelaskan tentang jenis data yang dikumpulkan dengan metode-metode yang terkait. Bagian ini juga memuat penjelasan secara lengkap dan terinci tentang jenis data yang diperlukan untuk analisis dalam pembahasan

\section{Metode Analisis Data (Optional)}

\section{Flowchart Perangkat yang akan di Rancang}

Pada gambar Flowchart diatas, menjelaskan bagaimana program cara kerja system robot lengan pemindah barang otomatis berbasis arduino menggunakan sensor warna. Saat alat di hidupkan, jika barang di letakkan di meja detektor sensor terbaca dan warna terdeteksi, posisi servo 1 bergerak maka servo 2,3, dan 4 mengambil dan barang terangkat, selanjutnya barang terpindahkan posisi servo 1 bergerak maka servo 2,3, dan 4 menjatuhkan, barang jatuh ke kotak

\section{Metode Testing}

Pada penelitian ini metode yang digunakan adalah Black Box Testing dan Metode pengujian blackbox diselenggarakan untuk mencari errorerror atau hilangnya fungsionalitas, desain antar muka, dan performanya. Kemudian mengamati apakah sudah berjalan sesuai dengan yang telah dirancang dan diinginkan.

Pengujian Black Box merupakan metode perancangan data uji yang didasarkan pada spesifikasi perangkat lunak dan fungsinya. Sehingga tidak membutuhkan coding

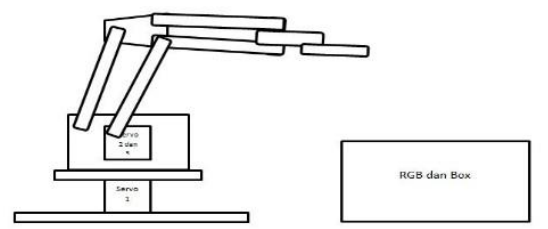

Gambar 3. 6 Rancang Mekanik Alat

dan juga tidak menguji perancangan internal software. Data uji dieksekusi pada perangkat lunak dan kemudian di cek apakah telah sesuai dengan yang diharapkan.

Pada bagian ini, pengujian dilakukan dengan memasukkan data sesuai prosedur untuk memastikan apakah realisasinya sesuai dengan yang diharapkan

atau tidak. Pengujian dilakukan pada fungsionalitas aplikasi yang meliputi fungsi-fungsi tombol dan fitur-fitur dalam aplikasi dan juga dilakukan pengujian terhadap fungsi diagnosis pada aplikasi. 3.8. Alur Penelitian
Penelitian ini dilakukan dengan beberapa tahapan antara lain, menentukan konsep penelitian, studi literature, menetukan rancangan, pengujian dan analisis, serta evaluasi.

\section{ANALISIS DAN PERANCANGAN SISTEM}

1. Analisis dan Rancangan Sistem

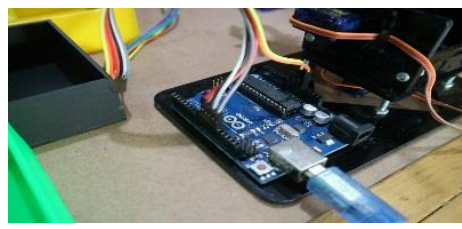

Perancangan sistem robot lengan pemindah barang otomatis berbasis arduino menggunakan sensor warna, sesuai dengan yang di bahas pada bab sebelumnya, dimana pembuatannya sesuai dengan rancangan yang telah di buat. Mengenai perancangan tersebut dapat disimpulkan membutuhan perangkat, baik perangkat keras maupun perangkat lunak, perancangan perangkat keras meliputi perancangan rangkaian arduino, servo, dan module RGB. Perancangan perangkat lunak meliputi pembuatan program pada software arduino IDE 1.0.5

\section{Perancangan perangkat keras}

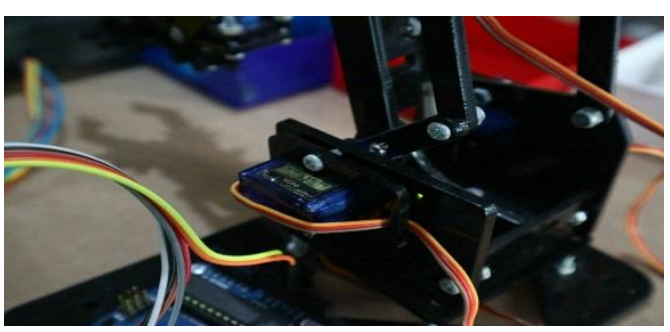

\section{a) Perancangan Rangkaian Arduino}

Pada perancangan ini, arduino uno sebagai pengendali utama dalam mengolahan data. Rangkaian arduino ini terhubung dengan Servo dan sensor RGB. Seperti gambar berikut

\section{Perancangan Servo}

Pada perancangan ini, servo sebagai pengendali robot lengan itu sendiri dan servo hanya terhubung dengan arduino. Seperti gambar berikut :

\section{b) Perancangan Rangkaian RBG (Red Blue Green)}

Pada perancangan ini, sensor RGB TCS3200 sebagai media pembaca warna. Apabila sensor RGB tersebut telah membaca warna maka dapat melakukan proses pemindahan barang sesuai warna tersebut. Seperti gambar berikut :

\section{Perancangan Perangkat Lunak}




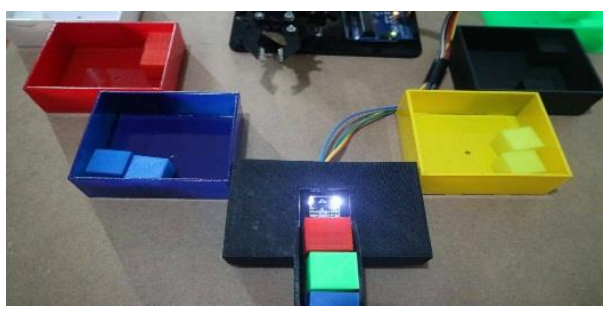

Program yang digunakan adalah arduino 1.0.5 untuk memberikan perintah kedalam arduino uno. Pengoperasian program ini dimasukkan kedalam arduino uno sebagai board controller.

Dof 4 yang di kendalikan melalui servo 4 akan bergerak dari titik 0 derajat menuju titik 60 derajat untuk membuka capit atau gripper untuk mengambil barang. Selanjutnya dof 3 yang di kendalikan melalui servo 3 akan bergerak dari titik 5 derajat menujuh titik 72 derajat menuju titik penempatan barang.

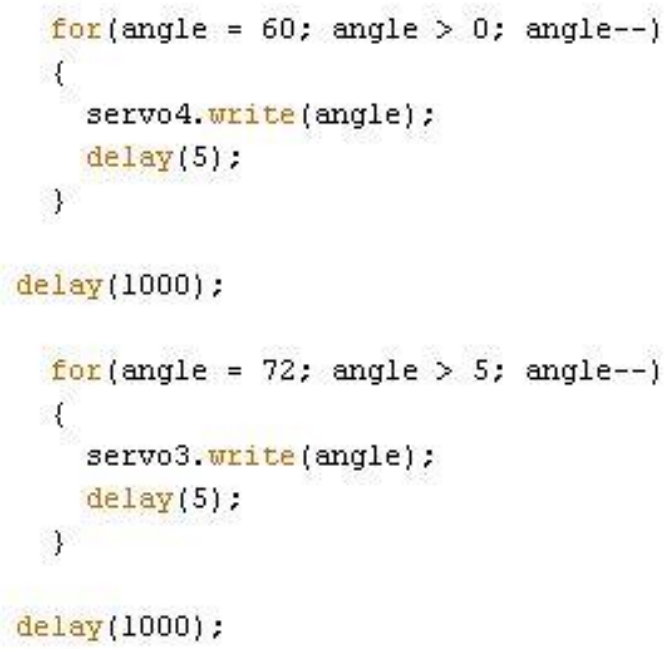

Kemudian sistem akan menerima tunda waktu selama 1 detik atau 1000 ms untuk setelahnya dapat di lanjutkan ke proses berikut :

Dof 4 yang di kendalikan melalui servo 4 akan bergerak dari titik 60 derajat menuju titik 0 untuk menutup capit atau gripper untuk mengambil barang. Selanjutnya dof 3 yang di kendalikan

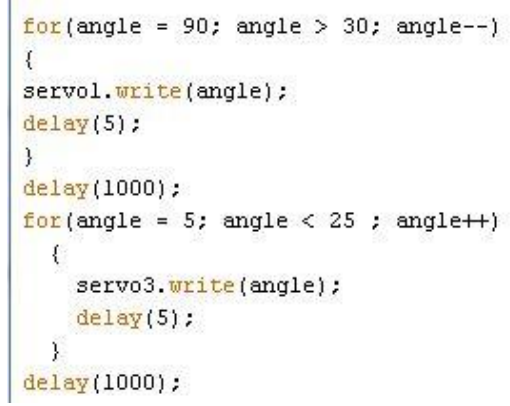

melalui servo 3 akan bergerak dari titik 72 derajat menuju titik 5 derajat menuju kembali ke titik awal. Kemudian sistem akan menerima tunda waktu selama 1 detik atau 1000 ms untuk setelahnya dapat di lanjutkan ke proses berikut :

Dof 1 yang di kendalikan melalui servo 1 akan bergerak dari titik 90 derajat menuju titik 30 derajat yang difungsikan untuk memposisikan lengan robor tepat pada arah wadah sesuai warna barang. Selanjutnya dof 3 yang di kendalikan melalui servo 3 akan bergerak dari titik 5 derajat menuju titik 25 derajat menuju titik tengah wadah barang. Kemudian sistem akan menerima tunda waktu selama 1 detik atau 1000 ms untuk setelahnya dapat di lanjutkan ke proses berikut :

Dof 4 yang di kendalikan melalui servo 4 akan bergerak dari titik 0 derajat

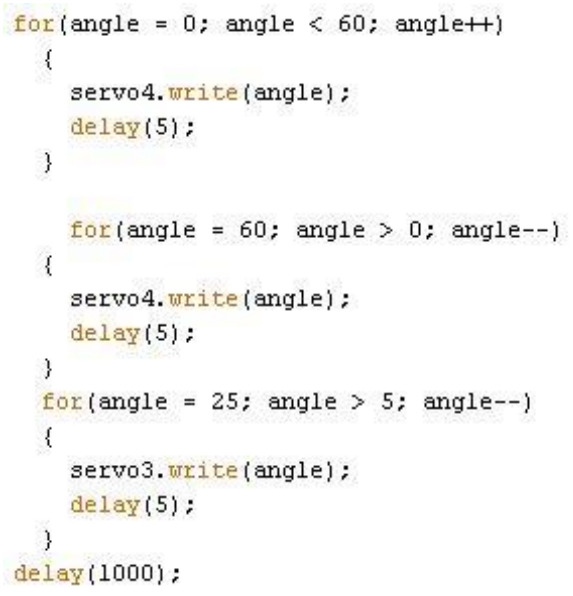

menuju titik 60 derajat untuk membuka capit atau gripper untuk melepas barang. Dof 4 yang di kendalikan melalui servo 4 akan bergerak dari titik 60 derajat menuju titik 0 untuk menutup capit atau gripper ke posisi awal. Selanjutnya dof 3 yang di kendalikan melalui servo 3 akan bergerak dari titik 25 derajat menuju titik 5 derajat menuju kembali ke titik awal. Kemudian sistem akan menerima tunda waktu selama 1 detik atau $1000 \mathrm{~ms}$.

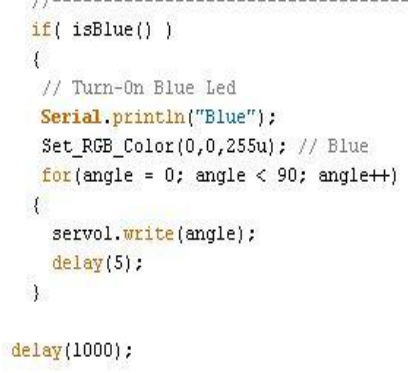

Pada gambar di atas menunjukkan program perintah gerak lengan robot di awal respon ketika sensor warna mendeteksi dan menentukan hasil pembacaan berubah warna biru maka dof 1 yang di kendalikan melalui servo 1 akan bergerak dari titik 0 derajat menuju titik 90 derajat menuju titik pengambilan barang. Kemudian sistem akan 
menerima tunda waktu selama 1 detik atau $1000 \mathrm{~ms}$ untuk setelahnya dapat di lanjutkan ke proses berikut :

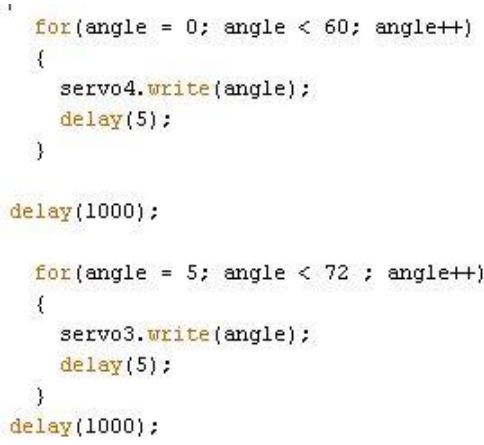

Dof 4 yang di kendalikan melalui servo 4 akan bergerak dari titik 0 derajat menuju titik 60 derajat untuk membuka capit atau gripper untuk mengambil barang. Selanjutnya dof 3 yang di kendalikan melalui servo 3 akan bergerak dari titik 5 derajat menujuh titik 72 derajat menuju titik penempatan barang. Kemudian sistem akan menerima tunda waktu selama 1 detik atau $1000 \mathrm{~ms}$ untuk setelahnya dapat di lanjutkan ke proses berikut :

Dof 4 yang di kendalikan melalui servo 4 akan bergerak dari titik 60 derajat menuju titik 0 untuk menutup capit atau

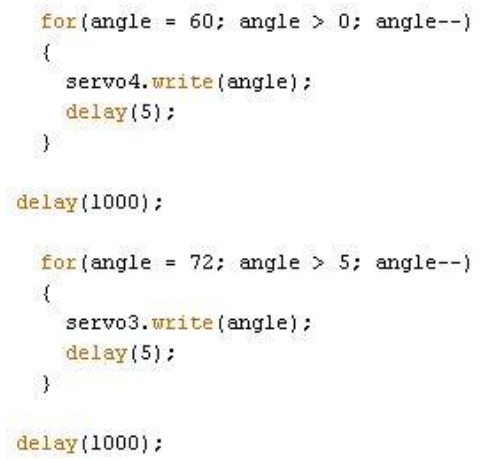

gripper untuk mengambil barang. Selanjutnya dof 3 yang di kendalikan melalui servo 3 akan bergerak dari titik 72 derajat menuju titik 5 derajat menuju kembali ke titik awal. Kemudian sistem akan menerima tunda waktu selama 1 detik atau $1000 \mathrm{~ms}$ untuk setelahnya dapat di lanjutkan ke proses berikut :

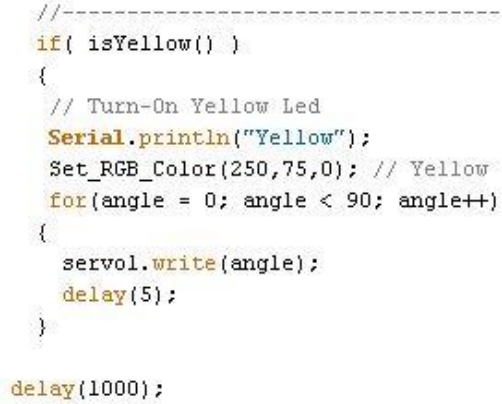

Dof 1 yang di kendalikan melalui servo 1 akan bergerak dari titik 90 derajat menuju titik 60 derajat yang difungsikan untuk memposisikan lengan robor tepat pada arah wadah sesuai warna barang. Selanjutnya dof 3 yang di kendalikan melalui servo 3 akan bergerak dari titik 5 derajat menuju titik 25 derajat menuju titik tengah wadah barang. Kemudian sistem akan menerima tunda waktu selama 1 detik atau 1000 ms untuk setelahnya dapat di lanjutkan ke proses berikut :

Dof 4 yang di kendalikan melalui servo 4 akan bergerak dari titik 0 derajat

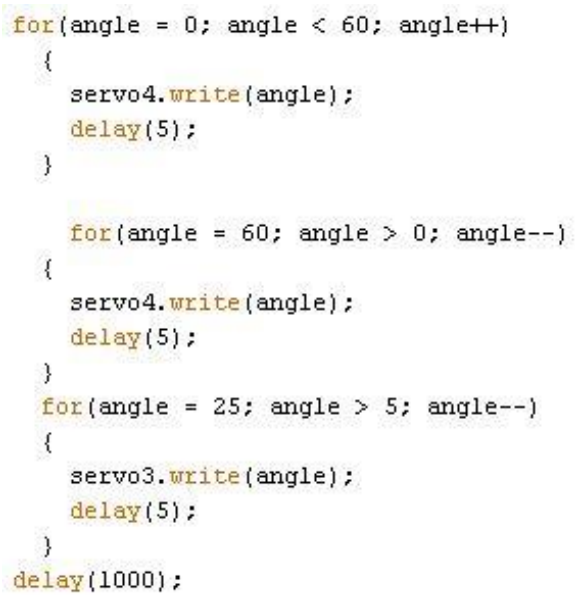

menuju titik 60 derajat untuk membuka capit atau gripper untuk melepas barang. Dof 4 yang di kendalikan melalui servo 4 akan bergerak dari titik 60 derajat menuju titik 0 untuk menutup capit atau gripper ke posisi awal. Selanjutnya dof 3 yang di kendalikan melalui servo 3 akan bergerak dari titik 25 derajat menuju titik 5 derajat menuju kembali ke titik awal. Kemudian sistem akan menerima tunda waktu selama 1 detik atau $1000 \mathrm{~ms}$.

Pada gambar di atas menunjukkan program perintah gerak lengan robot di awal respon ketika sensor warna mendeteksi dan menentukan hasil pembacaan berubah warna kuning maka dof 1 yang di kendalikan melalui servo 1 akan bergerak dari titik 0 derajat menuju titik 90 derajat menuju titik 
pengambilan barang. Kemudian sistem akan menerima tunda waktu selama 1 detik atau $1000 \mathrm{~ms}$ untuk setelahnya dapat di lanjutkan ke proses berikut :

Dof 4 yang di kendalikan melalui servo 4 akan bergerak dari titik 0 derajat

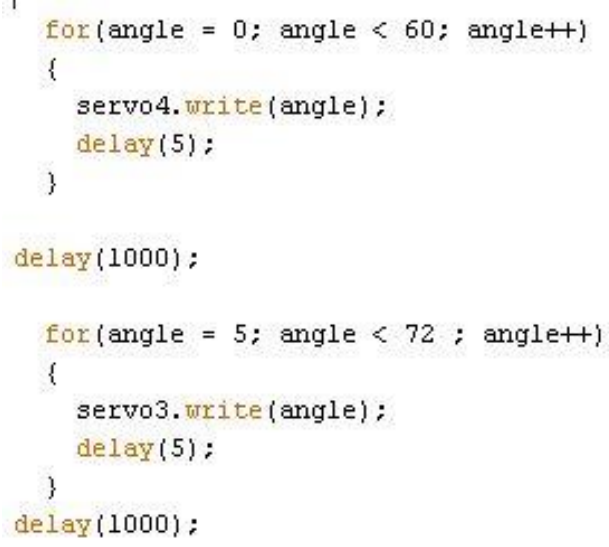

menuju titik 60 derajat untuk membuka capit atau gripper untuk mengambil barang. Selanjutnya dof 3 yang di kendalikan melalui servo 3 akan bergerak dari titik 5 derajat menujuh titik 72 derajat menuju titik penempatan barang. Kemudian sistem akan menerima tunda waktu selama 1 detik atau $1000 \mathrm{~ms}$ untuk setelahnya dapat di lanjutkan ke proses berikut :

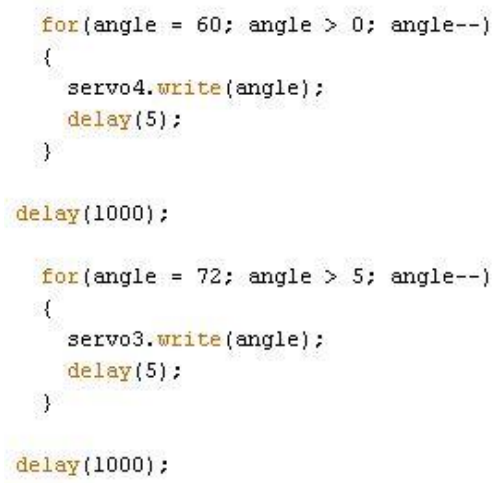

Dof 4 yang di kendalikan melalui servo 4 akan bergerak dari titik 60 derajat menuju titik 0 untuk menutup capit atau gripper untuk mengambil barang. Selanjutnya dof 3 yang di kendalikan melalui servo 3 akan bergerak dari titik 72

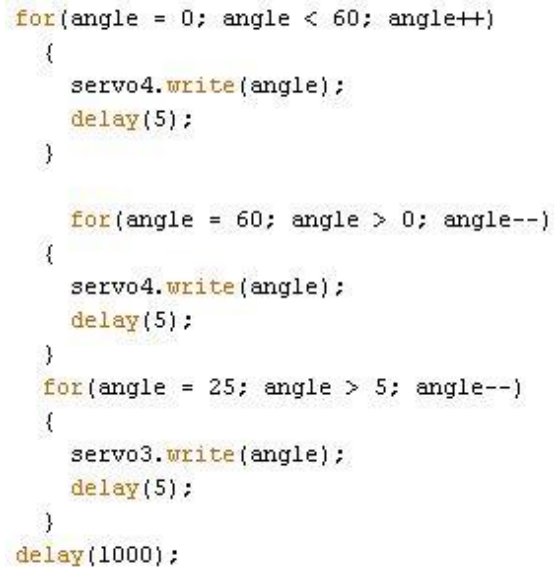

derajat menuju titik 5 derajat menuju kembali ke titik awal. Kemudian sistem akan menerima tunda waktu selama 1 detik atau $1000 \mathrm{~ms}$ untuk setelahnya dapat di lanjutkan ke proses berikut :

Dof 1 yang di kendalikan melalui servo 1 akan bergerak dari titik 90 derajat

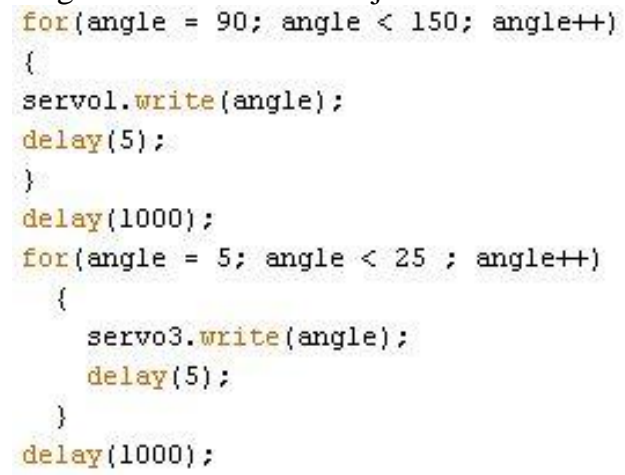

menuju titik 150 derajat yang difungsikan untuk memposisikan lengan robor tepat pada arah wadah sesuai warna barang. Selanjutnya dof 3 yang di kendalikan melalui servo 3 akan bergerak dari titik 5 derajat menuju titik 25 derajat menuju titik tengah wadah barang. Kemudian sistem akan menerima tunda waktu selama 1 detik atau $1000 \mathrm{~ms}$ untuk setelahnya dapat di lanjutkan ke proses berikut :

Dof 4 yang di kendalikan melalui servo 4 akan bergerak dari titik 0 derajat menuju titik 60 derajat untuk membuka capit atau gripper untuk melepas barang. Dof 4 yang di kendalikan melalui servo 4 akan bergerak dari titik 60 derajat menuju titik 0 untuk menutup capit atau gripper ke posisi awal. Selanjutnya dof 3 yang di kendalikan melalui servo 3 akan bergerak dari titik 25 derajat menuju titik 5 derajat menuju kembali ke titik awal. Kemudian sistem akan menerima tunda waktu selama 1 detik atau $1000 \mathrm{~ms}$. 
'Pada gambar di atas menunjukkan program perintah gerak lengan robot di awal respon ketika sensor warna mendeteksi dan menentukan hasil pembacaan berubah warna putih maka dof 1 yang di kendalikan melalui servo 1 akan bergerak dari titik 0 derajat menuju titik 90 derajat menuju titik pengambilan barang. Kemudian sistem akan menerima tunda waktu selama 1 detik atau $1000 \mathrm{~ms}$ untuk setelahnya dapat di lanjutkan ke proses berikut :

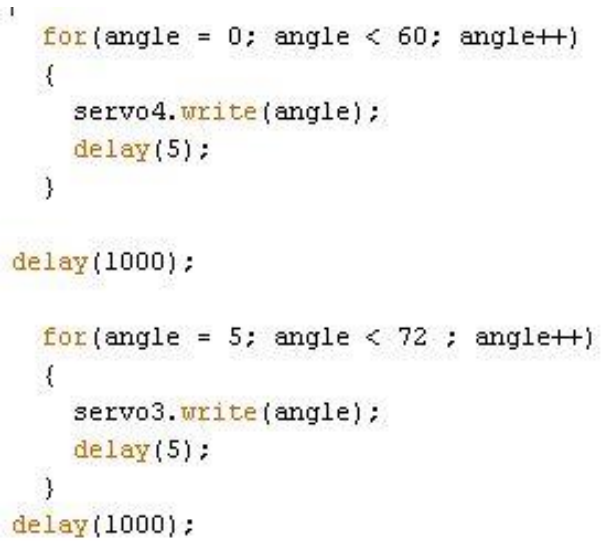

Dof 4 yang di kendalikan melalui servo 4 akan bergerak dari titik 0 derajat menuju titik 60 derajat untuk membuka capit atau gripper untuk mengambil barang. Selanjutnya dof 3 yang di kendalikan melalui servo 3 akan bergerak dari titik 5 derajat menujuh titik 72 derajat menuju titik penempatan barang. Kemudian sistem akan menerima tunda waktu selama 1 detik atau $1000 \mathrm{~ms}$ untuk setelahnya dapat di lanjutkan ke proses berikut :

Dof 4 yang di kendalikan melalui servo 4 akan bergerak dari titik 60 derajat menuju titik 0 untuk menutup capit atau gripper untuk mengambil barang. Selanjutnya dof 3 yang di kendalikan melalui servo 3 akan bergerak dari titik 72 derajat menuju titik 5 derajat menuju kembali ke titik awal. Kemudian sistem akan menerima tunda waktu selama 1 detik atau 1000 ms untuk setelahnya dapat di lanjutkan ke proses berikut :

Dof 1 yang di kendalikan melalui

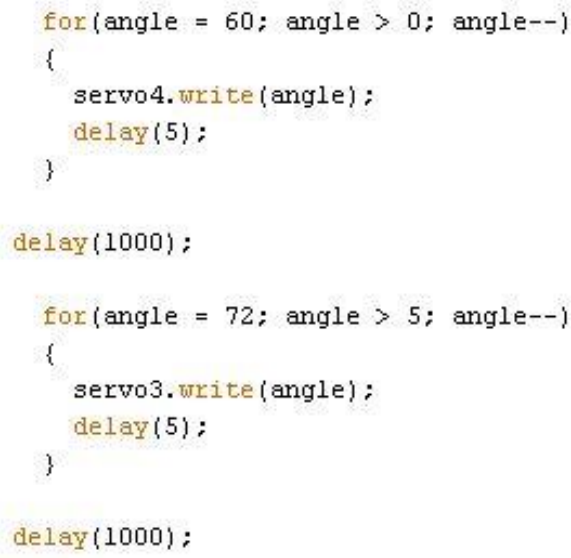

servo 1 akan bergerak dari titik 90 derajat menuju titik 0 derajat yang difungsikan untuk memposisikan lengan

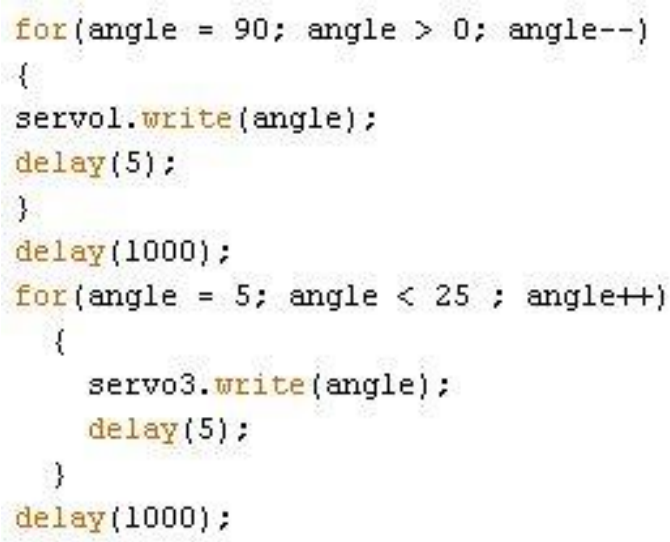

robor tepat pada arah wadah sesuai warna barang. Selanjutnya dof 3 yang di kendalikan melalui servo 3 akan bergerak dari titik 5 derajat menuju titik 25 derajat menuju titik tengah wadah barang. Kemudian sistem akan menerima tunda waktu selama 1 detik atau $1000 \mathrm{~ms}$ untuk setelahnya dapat di lanjutkan ke proses berikut :

Dof 4 yang di kendalikan melalui servo 4 akan bergerak dari titik 0 derajat menuju titik 60 derajat untuk membuka capit atau gripper untuk melepas barang. Dof 4 yang di kendalikan melalui servo 4 akan bergerak dari titik 60 derajat menuju titik 0 untuk menutup capit atau gripper ke posisi awal. Selanjutnya dof 3 yang di kendalikan melalui servo 3 akan bergerak dari titik 25 derajat menuju titik 5 derajat menuju kembali ke titik awal. Kemudian sistem akan menerima tunda waktu selama 1 detik atau $1000 \mathrm{~ms}$.

\section{Implementasi}

Bagian ini berisi uraian tentang implementasi sistem secara detail sesuai dengan rancangan dan berdasarkan komponen, tools, atau bahasa 
pemrograman yang dipakai. Hasil implementasi sistem yang dikembangkan harus didasarkan pada hasil analisis dan perancangan sistem dan sedapat mungkin siap diterapkan dalam kondisi lapangan yang sesungguhnya.

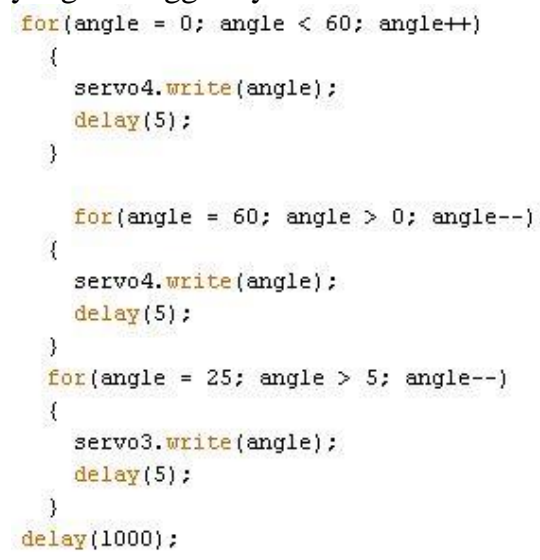

\section{Implementasi Arduino Uno}

Arduino uno merupakan bagian utama dan terpusat dari keseluruhan alat yang didalamnya telah terprogram untuk menjalankan fungsi alat yang dibuat. Implementasi yang dilakukan menghubungkan alat lainnya pada bagian masingmasing pin menggunakan kabel jumper. Adapun isi pin dari arduino uno yang diterapkan dengan komponen lainnya pada tabel dibawah ini :

Tabel 4.1 Implementasi Pin Arduino

\begin{tabular}{cc}
\hline PIN & FUNGSI \\
\hline 2 & Jalur Masuk Pin servo 1 \\
3 & Jalur Masuk Pin servo 2 \\
4 & Jalur Masuk Pin servo 3 \\
5 & Jalur Masuk Pin servo 4 \\
$\mathbf{8}$ & Jalur Masuk Pin SO RGB \\
$\mathbf{9}$ & Jalur Masuk Pin S1 RGB \\
$\mathbf{1 0}$ & Jalur Masuk Pin S2 RGB \\
$\mathbf{1 1}$ & Jalur Masuk Pin S3 RGB \\
$\mathbf{1 2}$ & Jalur Masuk Pin Sout RGB \\
$\mathbf{5 V}$ & Jalur masuk daya 5V \\
GND & Jalur masuk Ground \\
\hline
\end{tabular}

\section{Pengujian Sensor Warna (RGB)}

Sistem sensor warna adalah sistem yang merubah besaran panjang gelombang menjadi besaran tegangan sensor warna seri TCS3200 sangat akurat dan linier, tegangan output berbanding lurus dengan warna yang diterapkan. Sensor warna TCS3200 menggunakan catu daya dengan 4,8 - 5,4 VDC.

Pengujian sensor warna ini dapat dilihat pada serial monitor di bawah ini, dan adapun tabel hasil pengujian.

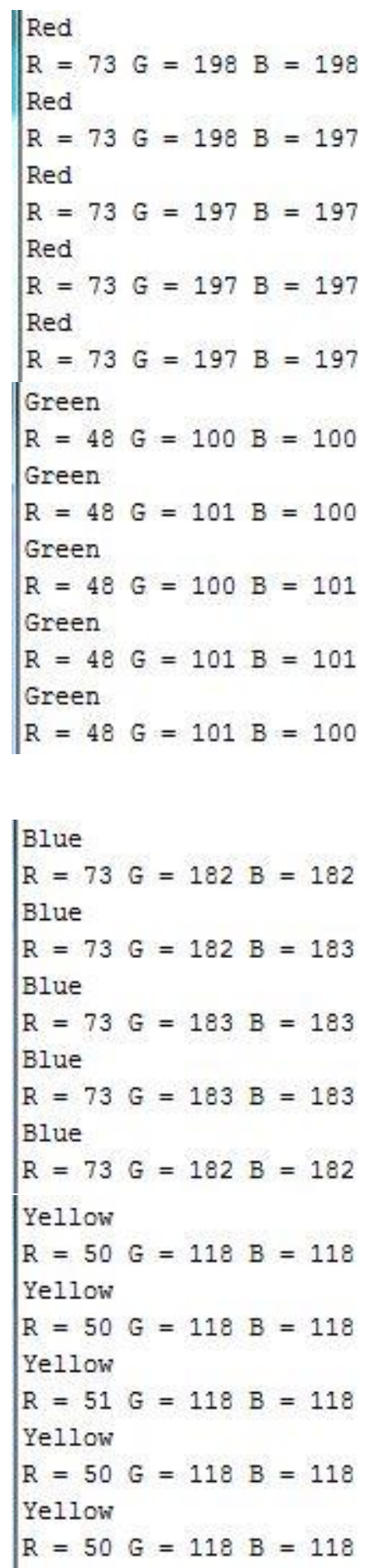

Gambar 4. 1 Penunjukkan angka hexadesimal dari pembacaan warna merah 


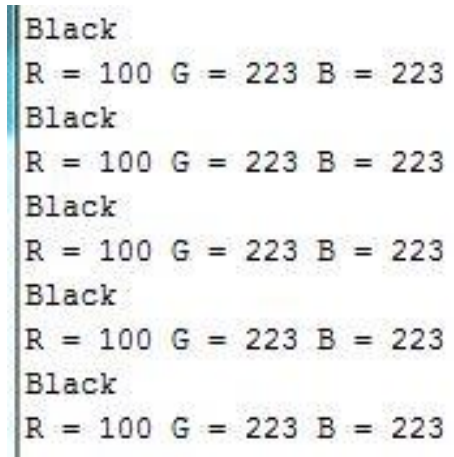

Gambar 4. 2 Penunjukkan angka hexadesimal dari pembacaan warna hitam

Tabel 4.2 Hasil Pengujian

\begin{tabular}{ccccc}
\hline \multirow{2}{*}{ NO } & Warna & RGB & Servo & Keterangan \\
& & & 1 & \\
\hline 1 & Merah & $76,207,206$ & $30^{\circ}$ & Sesuai \\
2 & Hijau & $50,104,105$ & $180^{\circ}$ & Sesuai \\
3 & Biru & $75,187,186$ & $60^{\circ}$ & Sesuai \\
4 & Kuning & $51,119,119$ & $120^{\circ}$ & Sesuai \\
5 & Hitam & $105,232,233$ & $150^{\circ}$ & Sesuai \\
6 & Putih & $34,93,93$ & $0^{\circ}$ & Sesuai \\
\hline
\end{tabular}

\section{PENUTUP}

\section{Kesimpulan}

1. Sensor warna TCS3200 dapat diimplementasikan sebagai pemilah warna hingga 25 varian warna, dan diaplikasikan sebagai penyortir barang berdasarkan warna.

2. Sebagai media angkut barang, lengan robot dapat diaplikasikan menggunakan beberapa servo dalam jumlah dof tertentu.

3. Servo SG90 mampu mengangkut beban hingga 90 gram dan diataur pada beberapa jenis kecepatan putaran.

\section{Saran}

Semulasi sistem yang dibuat berupa lengan robot dapat dimanfaatkan serta diimplemtasikan dalam sekala lebih besar untuk penggunaan yang kompleks dalam sektor industrial dan pabrikasi dengan upgrade komponen seperti servo dengan kemampuan angkut atau torsi yang lebih besar.

Kelemahan sistem yang menggunakan sensor warna TCS3200 adalah fluktuasi data pembacaan warna yang sangat dipengaruhi oleh itensitas cahaya, oleh karena itu desain mekanik sistem yang dibuat sangat disarankan berada pada ruang tertutup.

\section{DAFTAR PUSTAKA}

Asep Saefullah, Dewi Immaniar, Reza Amar Juliansah,2014,Sistem Kontrol Robot
Pemindah Barang Menggunakan Aplikasi Android Berbasis Arduino Uno, Online pada http://raharja.ac.id/raharja_file/file_jurnal/file/ 8020515.pdf. diakses tanggal 11 November 2017.

Mandari , Yopi dan Triyanto Pangaribowo,2016,Rancang Bangun Sistem Robot Penyortir Benda Padat Berdasarkan Warna Berbasis Arduino,Program Studi Teknik Elektro,Fakultas Teknik,Universitas Mercu Buana,Kembangan,Jakarta.

Nalwan. Andi. Paulus,2013,Aplikasi Penggerak Lengan Robot dalam memindahkan barang pada sistem roda berjalan,Delta Elektronik,Jakarta

Nyebarilmu.com, Cara Mengakses LED RGB dengan Arduino, Online pada https://www.nyebarilmu.com/caramengakses-led-rgb-dengan-arduino/ , diakses tanggal 11 November 2017.

Ramdhan,William dan Hizriani,2017,Perancangan Alat Penyortir Permen Berdasarkan Perbedaan Warna Menggunakan Sensor RGB LED Berbasis Mikrokontroler Arduino UNO, Jurnal Manajemen Informatika dan Teknik Komputer,Volume 2,Amik Royal Kisaran,Sumatra Utara.

Supegina, Fina dan Dede Sukindar,2014, Perancangan Robot Pencapit Untuk Penyotir Barang Berdasarkan Warna LED RGB Dengan Display LCD, Jurnal Elektro,Universitas Mercu Buana,Jakarta Barat.

Wardana, Gita Tri, Dedy Eko Setiawan, Abdul Rahman, dan Nanda Prasetia,2015,Robot Lengan Pemindah Barang Berdasarkan Ukurannya Berbasis Mikrokontroler, Teknik Komputer,AMIK MDP Palambang, Palembang.

Wijaya, Andri,2010,Studi Mobile Robot Pemindah Barang Berdasarkan Warnanya Berbasis Mikrokontroller AT89S52, Jurnal Publikasi,Fakultas Teknik,Departemen Teknik Elektro,Universitas Indonesia,Depok.

Yudhanto.Sigit,2011,Rancang Bangun Lengan Robot Pemindah Barang Berbasis Mikrokontroller ATMega16,Sains dan Teknologi,Universitas Airlangga, Surabaya. 